\title{
O TERROR EM ESTADO BRUTO
}

\author{
Jefson Jesus de Souza ${ }^{1}$
}

DELLILO, Don. Homem em QUEDA. Companhia das Letras. Iㄴa ed. 2007.

O estilo de Don DeLillo é conhecido pela maioria de seus leitores, um amplo horizonte entrelaçado de figuras históricas com indivíduos ficcionais. Nesse romance, porém, o único ser nomeado é Mohamed Atta, um dos mentores da tragédia do ir de Setembro. DeLillo mantém o foco numa família de classe média de Manhattan, oferece várias doses de silêncios e enigmas até a inesperada sequência final. O romance mantém-se, então, no que poderíamos chamar uma certa espiritualidade nouvelle vague. No entanto, ao invés de estabelecer com essa dicção a inércia, o efeito obtido é o de uma bomba devastadora revelando o terror em seu estado bruto.

Conhecemos Keith, um advogado de cerca de 40 anos de idade, que escapa das torres em queda, para logo aparecer na casa da ex-mulher, Lianne. Carrega a pasta de outra pessoa, situação que o ligará por um tempo a outro sobrevivente, "uma mulher de pele morena", de quem obtém sexo e lembranças daquele lugar devastado. Nas ruínas do in de Setembro a história parece sempre nos oferecer uma falsa confusão. A solidão impera de forma consumidora e as palavras agem em toda a sua fragmentação. Homem em Queda não se satisfaz com meros acasos e nos revela realidades distorcidas, uma visão estigmatizada de Keith que não impede que possamos, em meio aos seus devaneios, vislumbrar os escombros de seus pensamentos.

Quando em dado momento, no entanto, o escritor rompe essa atmosfera de distorção e passa a analisar o II de Setembro sob o ponto de vista dos sequestrados, tudo muda. Ele descreve com talento superior toda trama dos ataques que abalaram

\footnotetext{
I Graduando em medicina pela Universidade Federal do Sul da Bahia- UFSB. Email: negromontejeff@yahoo.com.br
} 
o mundo e expõe personagens que envolvem e reconstroem a trama de uma forma diferente.

O vilão, Bin Laden, não é citado. Há, apenas, uma possível aproximação de um inimigo chamado Bill Lawton, feita por garotos que vigiam, de binóculos, do vigésimo-sétimo andar de um prédio, os céus da cidade, rastreando os próximos aviões que serão enviados pelo inimigo.

Homem em Queda é um romance cuja forma e conteúdo não eclipsa a vida depois do ir de Setembro e seu título deriva da cena do homem que cai de cabeça da torre norte. Algo que realmente choca e estabelece a negra lembrança daquele fatídico dia. Todavia o que seu conteúdo engloba vai além, condensando, outras imagens, que logo chegam à mente, ora de forma sorrateira, ora de forma abrupta, demonstrando que estamos à deriva no que diz respeito à segurança e orando para que nenhum outro fanático religioso venha até a redoma do paraíso capitalista direcionar aviões sobre prédios gigantescos lotados de pessoas engravatadas e de salto alto.

O ódio e a loucura são palavras que flutuam sobre o ambiente de escombros provocado após o acontecimento e nos faz refletir sobre o que levou diretamente à situação fazendo comparecer perguntas em nossos pensamentos que parecem ficar sem respostas ou provocar novas perguntas impregnadas de absurdos. DeLillo é hábil ao transcorrer a reflexão e conduz o leitor no retorno à memória da tragédia. 